\title{
Association of breast cancer and CLL
}

\section{Meme kanseri ve KLL birlikteliği}

\author{
Yasemin Benderli Cihan
}

Kayseri Eğitim Ve Araştırma Hastanesi, Radyasyon Onkoloji, Kayseri, Türkiye

Doi: $10.5505 /$ aot.2012.88598

Anahtar Kelimeler: Meme kanseri, KLL; Senkron

Key words: Breast Cancer, CLL; Synchronous

\section{Sayın Editör,}

Aynı hastada eş ya da farklı zamanda birbirinden farklı tümörler gelişebilmektedir. Bir malignite seyrinde, ikinci kanser gelişsiminin \%0.7-11.7 oranında olduğu bildirilmektedir. Gelişim mekanizması ve etyolojisi tam aydınlatılmamış olmakla birlikte kalıtsal ve kazanılmış mutasyon neticesinde oluşabileceği üzerinde durulmaktadır. Meme kanseri seyrinde ikinci malignite olarak tiroid, akciğer, yumuşak doku sarkomu, endometrium kanserinin görüldüğü bildirilmiştir (1). Kronik lenfoid lösemide (KLL) ise cilt, prostat, over ve endometrium kanseri eş zamanlı görülebilmektedir (2). $\mathrm{Bu}$ yazıda, meme kanseri seyri sırasında KLL gelişen hasta sunuldu.

Elli iki yaşında bir kadın hasta yaklaşık bir aydır sağ göğüste ele gelen şişlik şikâyeti ile Temmuz 2005 'te genel cerrahi polikliniğine başvurduğu öğrenildi. Hastanın meme ultrasonografisinde sağ memede saat 3 hizasinda areolanın $2 \mathrm{~cm}$ lateralinde yaklaşı $32 \times 34 \mathrm{~mm}$ ebadında düzensiz sinırlı, hipoekoik, heterojen solid lezyon izlendi. Sağ aksillada büyüğü $12 \times 14 \mathrm{~mm}$ boyutta üç adet hipoekoik, vaskülaritesi belirgin artmış lenfadenopatiler görüldü. Yapılan ince iğne aspirasyon biyopsisinde malignite lehine gelmesi üzerine Ağustos 2005'te sağ modifiye radikal mastektomi yapıldi. Operasyon materyalinin patolojik değerlendirmesinde; sağ meme invaziv duktal karsinom, tümör çap1 $4 \mathrm{~cm}$, diseke edilen lenf nodundan 10 tanesinde karsinom metastazı, östrojen reseptörü, progesteron reseptörü ve HER-2 negatif olarak rapor edildi. Olguya 6 kür kemoterapi sonras 1 gögüs bölgesi ve periferik lenfatiklere $50 \mathrm{~Gy}$ radyoterapi verildi. Takiplere alınan hasta Nisan 2006'da hafif akciğer enfeksiyonu gelişmesi ve rutin kan tetkiklerinde lenfositoz saptand1 (lökosit: 26x10 $/ \mathrm{L}$, (\%80 lenfosit). Platelet ve hemoglobin normal saptandi. Hematoloji bölümünce bu değerler tetkik edilerek periferik yaymada olgun lenfositoz, basket hücreleri, \%11 altında prolenfosit; akımsitometri sonucu da CD5 ve CD19 pozitif, CD23 hafif pozitif, cyclin D1 negatif saptand1. Kemik iliği biyopsisinde nodüler tarzda kemik iliği olgun lenfosit hücre infiltrasyonu, \%30 üzerinde lenfoid infiltrasyon, low grade lenfoma ile uyumlu kemik iliği görünümü rapor edildi ve Evre IA KLL tanısı konulup ilaçsız takibe alındı.

Kanserli hasta takip edilirken ikinci bir hematolojik kanser olabileceği veya gelişebileceği akılda tutulmalıdır. Nadirde olsa meme kanseri, KLL ile birlikte görülebilmektedir.

\section{Çıkar Çatışması: Yok}

\section{Kaynaklar}

1. Karabulut B, Saydam G, Özmen M et al. Meme kanseri ve KLL birlikte görülmesi: olgu sunumu. Türk Hematoloji-Onkoloji Dergisi 2001;11:91-4

2. Konuk N, Aydoğdu N, Kavukçu Ş. KLL ve küçük hücreli akciğer kanseri ve tüberkuloz beraberliği. Türk Hematoloji-Onkoloji Dergisi 1994;4:121-3 